\title{
THE POTENTIAL OF SOCIAL MEDIA CAMPAIGN CHALLENGE TOWARDS PHYSICAL ACTIVITY IN MODERN ERA
}

Nurlienda Hasanah*, Hafidhotun Nabawiyah", Yeni Tri Herwanto**

*Department of Biostatistics, Epidemiology and Population Health, Faculty of Medicine, Public Health and Nursing, Universitas Gadjah Mada

\section{INTRODUCTION}

Physical inactivity is one of the leading risk factor for non-communicable diseases in the world. Globally, the insufficient of physical activity is experienced by $25 \%$ of adults and $80 \%$ of adolescents. The lifestyle of adolescents and adults are increasingly tied to social media. More than $87 \%$ of netizens in Indonesia access social media. Social media is used to communicate and it can form social support including healthy behavior awareness.

\section{OBJECTIVE}

The aim of this study is to explore netizens response on Promkes.net social media campaign "\#7HariMelawanMager" challenge (Seven-days challenge beat physical inactivity).

\section{METHODS}

This study was a literature review, using supported document and challenge mini-survey on Instagram story and Facebook polling in a day and interview with challenge's founder.

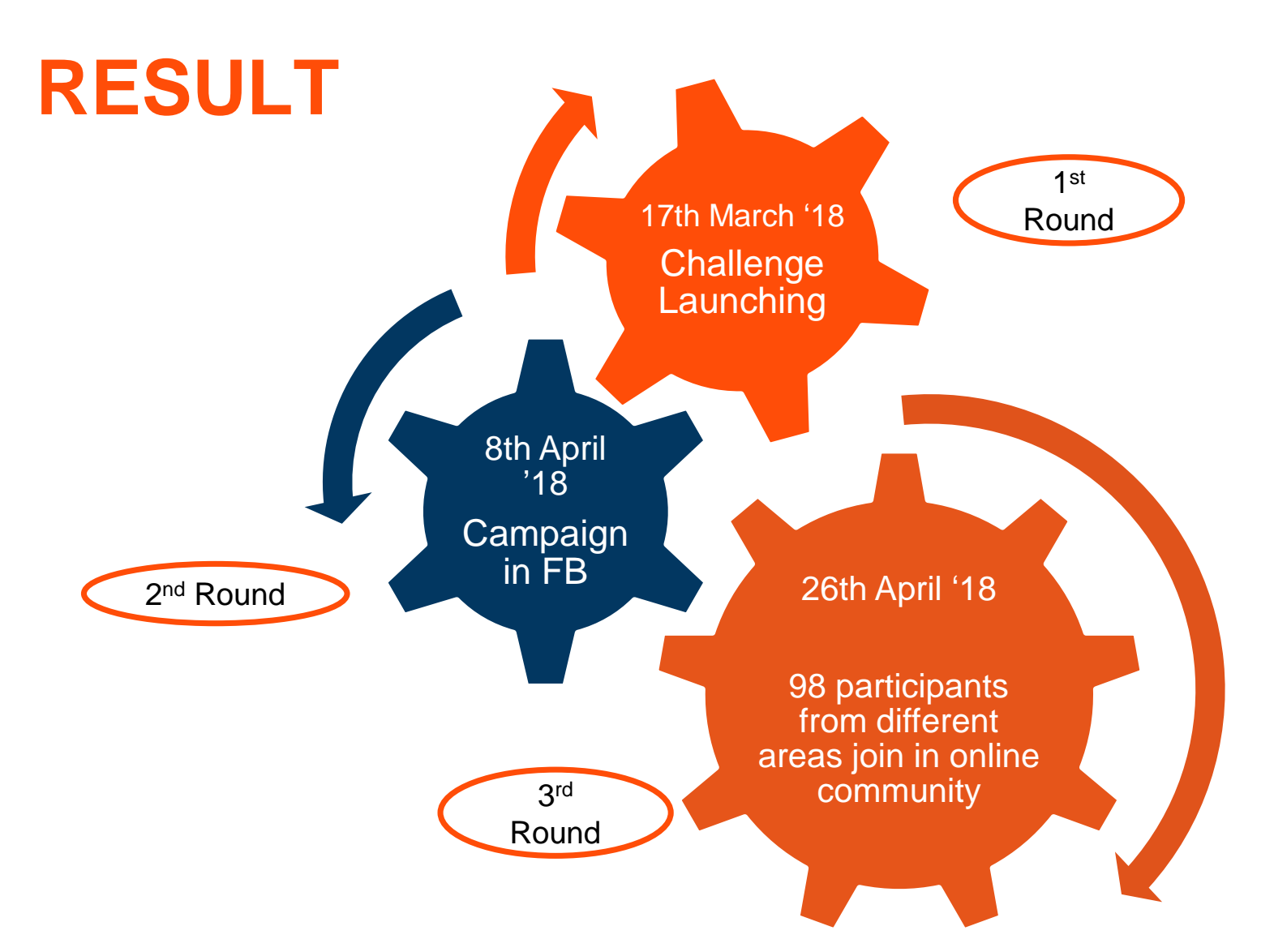

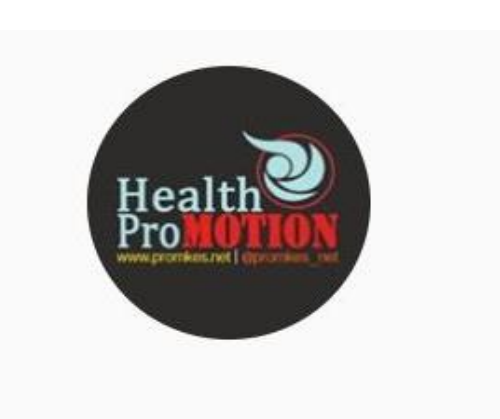
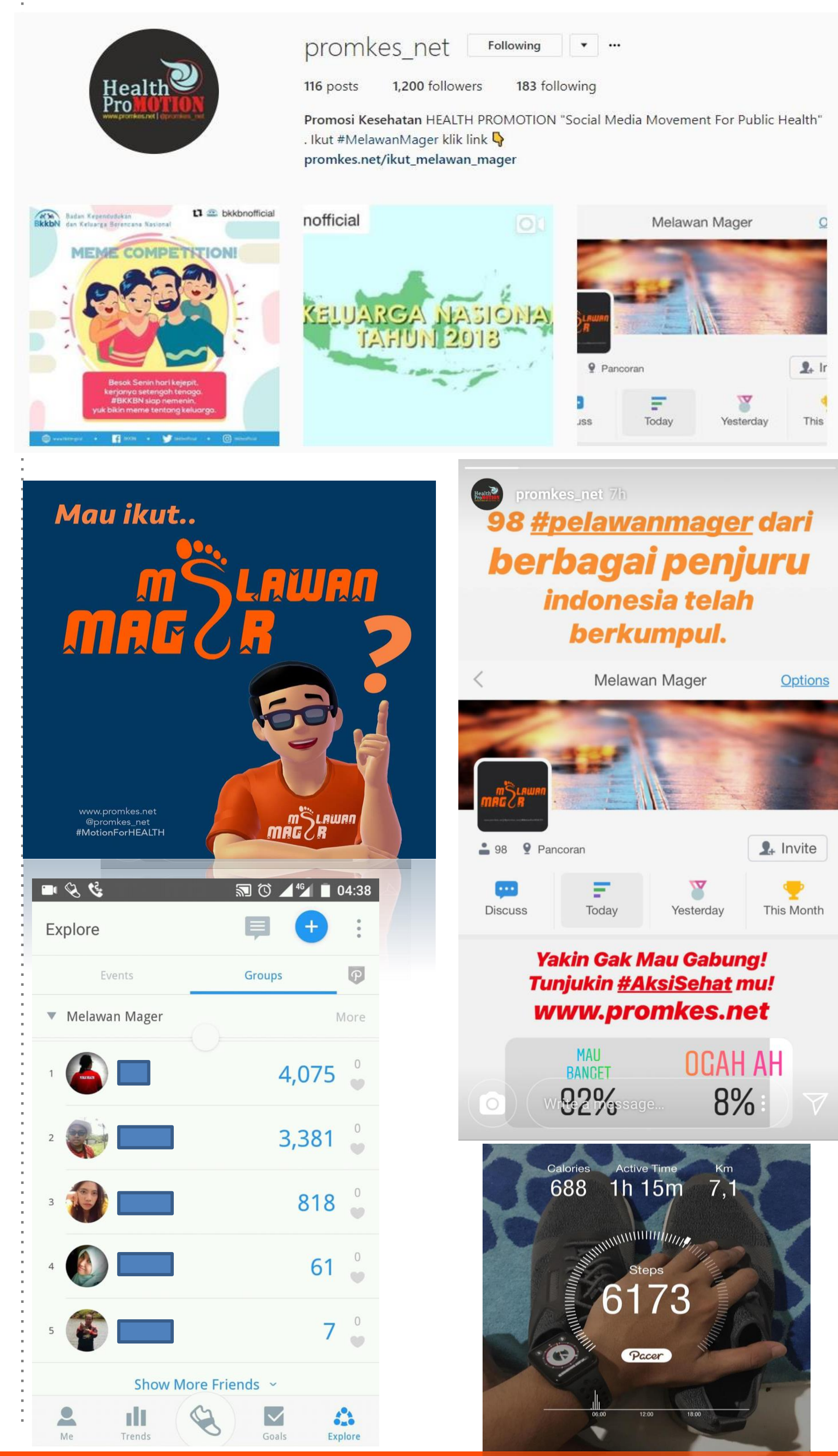

The campaign have been launching at $17^{\text {th }}$ March 2018 and there are several people join the challenge. As the result in three weeks, after the \#7HariMelawanMager challenge launched, there were 41 posts in Instagram with netizens completed the challenge. The social media challenge raising physical activity awareness from the communily. Yet there were 17 netizens who fulfill the @promkes_net Instagram story survey and 5 of 15 netizens did not know the campaign through Facebook's
author polling. At the end of the review, there are 98 netizens joining "Melawan Mager" Pacer group.

They are affiliate in online community based on Facebook and also do sharing \& motivating each other at the Pacer Pedometer application. People who are interested in this challenge can follow these steps to participate the challenge:

1. Apply the Pacer Pedometer application in smartphone Pacer Pedometer \& Step Tracker by Pacer Health (Android or iOS (iPhone)

2. Posting how many steps (minimum 2000 steps) everyday with hastag \#7harimelawanmager and challenge three different friends every day in social media (Facebook or Instagram)

3. Promkes.net develop online community "Melawan Mager" in Pacer Pedometer application. The community was built as sharing facility and to motivate each other. They make a great competition monthly and giving attractive prize as reward. 9 netizens completed and 33 posts in Facebook with 13

\section{CONCLUSIONS}

Health campaigns through social media \#7HariMelawanMager have the potential to increase awareness of physical activily. However, his campaign needs to consider the sustainability. Furthermor, netzens will better understand the benefits of physical activity to improve their quality of life.

\section{REFERENCES}

[1] WHO. Physical activity: key facts. 2018. http://www.who.int/news-room/fact-

sheets/detail/physical-activity
[2] Asosiasi Penyelenggara Jasa Internet Indonesia. Survei Penetrasi \& Perilaku Pengguna Inernet Indonesia. 2017

Lupton, Deborah. Health promotion in the digital era: A critical commentary

4] Norman, Cameron D. Social media and health promotion. Global Health

Promotion 2012. 19(4); 3-6
[5] Livingston James D, Michelle Cianfrone, Kimberley Korf-Uzan, Connie

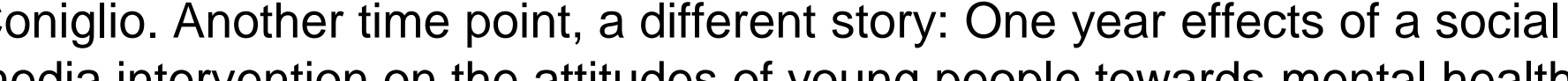
issues. Social Psychiatry and Psychiatric Epidemiology 2014. 49(6):985-990 Korda Holly, Zena Itani. Harnessing social media for health promotion and behavior change. Health promotion practice 2013. 14(1):15-23

Viswanath. health promotion: a content analysis. BMC public health 2013. 13(1):1129

[8] Bauman Adrian, Dafna Merom, Fiona C. Bull, David M. Buchner, Maria A. Fiatarone. Updating the Evidence for Physical Activity: Summative Reviews "Active Epidemilological Evidence, Prevalence, and Interventions to Promote

10] Masdal A Lidal ID, Strauman GH, Vis GE. Ta interventions promoting healthy behaviours to reduce risk of noncommunicable diseases in adult, ethnic minorities. Cochrane Database of 